\title{
MDH2 Gene
}

National Cancer Institute

\section{Source}

National Cancer Institute. MDH2 Gene. NCI Thesaurus. Code C124983.

This gene plays a role in the metabolism of both carbohydrates and oxoacids. 